\title{
Engaging with the South African Past: The TRC and How Theatre Performs Back
}

\section{Francesca Mussi}

\section{(2) OpenEdition \\ 1 Journals}

Electronic version

URL: https://journals.openedition.org/ces/4978

DOI: $10.4000 /$ ces.4978

ISSN: 2534-6695

Publisher

SEPC (Société d'études des pays du Commonwealth)

\section{Printed version}

Date of publication: 1 September 2015

Number of pages: 91-101

ISSN: 2270-0633

\section{Electronic reference}

Francesca Mussi, "Engaging with the South African Past: The TRC and How Theatre Performs Back", Commonwealth Essays and Studies [Online], 38.1 | 2015, Online since 10 April 2021, connection on 10 July 2021. URL: http://journals.openedition.org/ces/4978; DOI: https://doi.org/10.4000/ces.4978

\section{(c) (i) $\odot$}

Commonwealth Essays and Studies is licensed under a Licence Creative Commons Attribution - Pas d'Utilisation Commerciale - Pas de Modification 4.0 International. 


\section{Engaging with the South African Past: The TRC and How Theatre Performs Back}

Focusing on the analyses of two exemplary South African plays - Ubu and the Truth Commission, and Nothing But the Truth - this essay explores how the country has been negotiating its traumatic past through the Truth and Reconciliation Commission. These plays use dramatic performance to challenge and expose some weaknesses of the TRC - regarding, in particular, the concepts of truth, amnesty, and reconciliation - suggesting the necessity to keep the dialogue about the past open.

Truth commissions have become a common pathway in the landscape of countries experiencing a period of transition from authoritarian systems and civil conflicts to a democratic regime. Since 1974 there have been thirty truth commissions around the world, but it was the South African Truth and Reconciliation Commission (TRC) that captured worldwide attention due to its extensive media coverage, both domestically and internationally. The TRC was, indeed, one of the first truth commissions to take place in the public eye. Not only were the hearings held in front of a live audience, but they were also broadcast throughout the country for the sake of transparency, and as a fundamental part of the restoring and reinventing process that was meant to engage all South African people.

Since the first democratic elections in 1994 and the nomination of Nelson Mandela as President of the Republic of South Africa, the country has been engaged with looking back to its traumatic past under apartheid conditions and with creating a single, coherent national narrative of the "rainbow nation." The establishment of a Truth and Reconciliation Commission in 1995 played a fundamental role in this process of historical, political and social redefinition. Authorized by the Promotion of National Unity and Reconciliation Act, the TRC was set up "to provide for the investigation and the establishment of as complete a picture as possible of the nature, causes and extent of gross violations of human rights committed" (Promotion of National Unity and Reconciliation Act, No. 34 of 1995) during a 34-year period of South African history (1960 to 1994). The mandate of the Commission - carried out through three committees: Amnesty, Reparation and Rehabilitation, and Human Rights Violations specified the following goals: to investigate past gross human rights violations, afford victims an opportunity to relate the violations they suffered, grant amnesty to persons who committed abuses during apartheid - as long as crimes were politically motivated and there was full disclosure by those seeking amnesty,$-{ }^{1}$ take measures toward restoring human dignity, report to the nation about its findings, and make recommendations aimed at preventing gross violations of human rights in the future.

1. According to the Promotion of National Unity and Reconciliation Act of 34 (1995), amnesty ought to be granted in respects of acts, offences and violations associated with political objectives in the course of the conflicts of the past. Besides meeting these requirements, amnesty applicants had to make full disclosure of all the relevant facts relating to such acts. These full confessions by perpetrators were aimed at contributing to facilitating reconciliation and giving victims closure about their past suffering. 
In his personal memoir No Future Without Forgiveness, TRC Chairperson Archbishop Desmond Tutu outlines all the phases that resulted in the establishment of the Commission, and places particular emphasis on an urgent question which needed to be addressed: how could South Africans deal with the past? The Archbishop also points out that "the past, far from disappearing or lying down and being quiet, is embarrassingly persistent, and will return and haunt us unless it has been dealt with adequately. Unless we look the beast in the eye we will find that it returns to hold us hostage" (31). According to him, the Commission provided a better way of dealing with South Africa's painful past and getting at the truth than a criminal trial or the provision of a general amnesty. He underscores the necessity both to restore victims' dignity and humanity and forgive the perpetrators as fundamental requirements to build a better future for all South Africans, in spite of race, class, or gender. This "third way" of a truth and reconciliation commission allowed victims to tell their stories and share their suffering in public, in addition to permitting perpetrators to acknowledge their crimes and ask for forgiveness. In chapter twenty-one, entitled "Without forgiveness there is really no future," Tutu explains that "in forgiving, people are not being asked to forget," (219) but, on the contrary, it is really paramount that people remember, the wrongdoer confesses, and the victim forgives so that the process of reconciliation can begin in South Africa. Held under the banner "Truth: the road to reconciliation," the TRC public hearings aimed at the painful task of determining the "truth" about South African violent history on the assumption that only truth could actualize reconciliation among the people of South Africa.

Despite the fundamental contribution to the reconciliation of the country and the building of a collective historical narrative, the TRC was highly criticized for its emphasis on "extraordinary" event-based bodily violations which had occurred under apartheid conditions. Indeed, only those victims who suffered the kind of exceptionally violent treatment - torture, abduction, rape, the murder of a loved one - could attend the TRC victim hearings, largely preventing the greater non-white South African population that suffered the more ordinary, systematic and daily subjugation of the apartheid regime from participating in the healing process promoted by the Commission. Moreover, reparations to survivors and the families of victims were generally regarded as inadequate and have been slow to materialize. On the other hand, offenders were guaranteed amnesty from prosecution if they agreed to appear before the TRC and tell the whole truth about the crimes they had committed for political motives. Despite the uniqueness of its amnesty provisions, the South African Commission has not escaped some criticisms from the international human rights community, and the provision of amnesty still remains a source of controversy and heated debate. ${ }^{2}$

In South African Performance and Archive of Memory, Yvette Hutchison highlights the interdependent relationship between memory and performance, arguing that:

[performance] has been central to these processes of negotiating memory in a number of ways: insofar as public events have been used to foreground particular memories and histories, in the way in which theatrical productions have supported or challenged

2. Many critics have in fact raised some questions and objections about the efforts and the achievements of a truth commission in comparison with the criminal justice system: can justice in its different forms be served equally well with truth commissions? Should standard forms of prosecutions, such as trials, be preferred? Does the amnesty process comply with various criteria for justice, or does it undermine the trial system? In this respect, it is important to highlight that the TRC was intended from the outset to be a restorative rather than a retributive justice process. 
these performances of memory, and in the way a performance lens can further nuance particular formulations of memory. (2)

Drawing on Hutchison's assumption, this article explores the connections between the reconciling project of the TRC and two productions, namely, Ubu and the Truth Commission (1998) written by Jane Taylor - an experimental work which combines live acting with puppetry, video, and recorded sound effects and music -, and a less overtly performative, more traditionally text-based play Nothing But the Truth (2002) by John Kani. Both works respond to Shane Graham's challenge "for writers and artists [...] to tell the story in such a way that it re-enacts its own paradoxes and displacements, but without displacing the survivors from their own tales altogether, and without locking these survivors into a fixed narrative formula" ("The Truth Commission" 28). These texts invent new ways of dealing with the haunting past and with questions of memory and of representation. They particularly engage with the multi-layered concept of "truth," whose complexity had also emerged in the various debates that occurred before and during the life of the Commission, resulting in four typologies of "truth": factual or forensic truth; personal or narrative truth; social or "dialogue" truth, and healing and restorative truth (TRC Final Report, vol. 1 110-14).

Factual or forensic truth refers to the legal or scientific notion of truth as facts corroborated by evidence. Personal or narrative truth refers to a more subjective version of truth, which attempts to "capture the widest possible record of people's perceptions, stories, myths and experiences" and gives everyone who had been voiceless for so long "a chance to tell his or her truth as he or she sees it." Social or "dialogue" truth aims to promote "transparency, democracy and participation in society [...] as a basis for affirming human dignity and integrity," trying to transcend all the divisions of the past. Finally, healing and restorative truth was central to the work of the Commission and results from the story-telling process and the acknowledgment of past abuses, which contributed to the reparation of the damage inflicted during the regime and to the prevention of the recurrence of those abuses in the future.

As mentioned above, one of the TRC's main goals was to "compile as complete a picture as possible" (TRC Final Report, vol. 1. 24) of the events and of the gross human rights violations committed within or outside South Africa in the period 19601994. The Promotion of National Unity and Reconciliation Act also required that the Commission "prepare a comprehensive report which sets out its activities and findings, based on factual and objective information and evidence collected or received by it or placed at its disposal" (TRC Final Report, vol. 1 111). The pursuit of this forensic truth explains the Commission's focus on gathering cold facts, verifiable information, which often overcame some aspects of personal or narrative truth - such as people's emotions, perceptions, silences, cries. Indeed, while selecting those stories that met the Commission's criteria and could be heard at the public hearings, statement-takers were asked to use a standard form to record people's stories, which inevitably led to overlooking the emotional dimension of people's personal truths. Furthermore, the possibility for witnesses to tell their stories in the languages of their choice - even if these languages fell outside of the eleven official languages of South Africa - had a great impact on the transmission of "personal truth." This polylingual and heteroglossic provision, in fact, demanded the establishment of an extensive translating and interpreting service, 
which had the task of conveying the essential meaning of the testimonies - and not a word-for-word translation.

English was the fundamental language of translation in the public hearings; this meant that while witnesses were giving their testimonies in their preferred language, translators and interpreters sat in booths and simultaneously translated into English. This translation was then relayed to other translators whose assignment was to translate it into Afrikaans, the dominant language of the region where the hearings were held, and another language of that region. In addition to the predictable risk of losing some aspects of the testimonies from translation to translation, the stress experienced by interpreters who had to translate highly emotive material in the first person must also be taken into account when considering the quality of the translation itself. In Country of My Skull, a memoir of the TRC written by the South African poet and journalist Antjie Krog who had been invited to cover the public hearings, Krog reports some extracts of a young Tswana interpreter's interview, where the interpreter confesses that "it is difficult to interpret victim hearings [...] because you use the first person all the time. I have no distance when I say 'I' ... it runs through me with I' (195). Indeed, the interpreters, along with the journalists covering the hearings, were provided with counseling because of the profound identification with the witnesses and the more general impact of the victims' painful stories of suffering and violence they had to translate.

In this regard, Hutchison emphasizes that "language and memory are particularly challenged in the context of pain and horror, which in turn means that non-verbal expressions often substitute for, or reveal gaps in, the narrative" (32). As a consequence, some aspects of the testimonies - namely those which fall into the category of "personal or narrative truth" such as repetitions, ellipsis and silence, tone of voice, gaps in information, fluctuations in narrative time, gestures - could not be included in the transcripts, reports or the overall written archives because they simply were beyond interpretation and transcription. The combination of the inevitable losses deriving from the translating process and the condition of unspeakability of trauma resulted in a reduced version of truth, lacking in nuance and emotional content. Moreover, in this context of historical nation-building carried out by the TRC, there is also the added danger of consciously or unconsciously appropriating the narrative of other people's stories of suffering and pain. Hence, I have chosen to explore two plays which deploy dramatic performance to challenge and expose some weaknesses of the TRC proceedings, especially in connection with the concept of truth; they reflect on the complexities of telling various truths, and underscore the necessity for dialogue and negotiation at a more personal level with conflicting memories of trauma.

Written by Jane Taylor, Ubu and the Truth Commission (Ubu) is the third co-production between William Kentridge (also its director) and the Handspring Puppet Company, and its storyline is made more complicated by the interpolation of actual testimony extracts from the TRC hearings, puppetry, videos, and sound effects. Besides being a representation of, and a commentary on, the Truth Commission, the play is also textually indebted to Alfred Jarry's Ubu Roi (1896) as acknowledged by Taylor in her writer's note in the hardcopy of the play. Jarry's play was conceived as a play for marionettes and follows the political and criminal undertaking of Ubu, a sort of parodic Macbeth, who, together with his wife, attempts to grab all the power for himself. Taylor's play thus combines the wild burlesque of Jarry's creation with the gravitas of the truth commis- 
sion. The play is set during the years of the TRC hearings, and the main protagonists are $\mathrm{Pa}$ Ubu and his wife Ma Ubu, the only characters played by human actors, whose acting is complemented by the presence of puppets and their puppeteers. Pa Ubu is a composite figure playing the part of an undercover agent of the apartheid state responsible for many atrocities (torture, killing, etc.). In order to make his character more credible, Taylor even uses some lines from real death squad commanders Eugene De Kock and Dirk Coetzee and other famous agents of the former regime.

It is worth noting that the name Ubu ironically recalls the word Ubuntu, the African philosophy which, alongside Christian theology, constituted the spiritual and philosophical framework of the TRC. This connection is particularly paradoxical due to the opposing worldviews which Ubu and Ubuntu symbolize: whereas the former stands for the violence of the apartheid state - in this case embodied by $\mathrm{Pa} \mathrm{Ubu}-$, the latter appeals to human compassion and empathy. According to this African philosophy, a person with Ubuntu is aware of belonging to a greater whole, and aware that people are all interconnected; this means that we are diminished when others are humiliated or oppressed; we are dehumanized when we dehumanize the other:

None is an outsider, all are insiders, all belong. There are no aliens, all belonging in the one family, God's family, the human family. There is no longer Jew or Greek, male or female, slave or free - instead of separation and division, all distinctions make for a rich diversity to be celebrated for the sake of the unity that underlies them. We are different so that we can know our need of one another, for no one is ultimately self-sufficient. (Tutu 214-5)

There is no explicit indication from either the writer or the producers that this ironical opposition between Ubu and Ubuntu played a determining role in the choice of the character's name, but this apparent coincidence could not be ignored in the analysis of the play.

At the beginning of the play, Ma Ubu is ignorant of her husband's real job, and suspects that his nocturnal excursions are caused by his many marital infidelities. When she finally learns the truth, the woman weeps, not from shock but from pride: "the sly old jackal. I had no idea Pa was so important! All along, I thought he was betraying me and here he was, hard at work, protecting me from the Swart Gevaar" (Ubu 45). Lesley Marx underlines Ma Ubu's ambivalent character, which is further conveyed by the fact that her role is played by a black woman in a white face paint: "she is at once the ambitious ruthless and cunning Lady Macbeth, and the round, sensual, brutalized Ma Ubu" (215). On the one hand, the woman is the wife of a brutal agent of the apartheid regime who rejoices after discovering her husband's real activities. She also attempts to sell the documents proving $\mathrm{Pa}$ Ubu's involvement in apartheid atrocities to the highest bidder so as to gain some attention from the media. On the other hand, she speaks African languages and works as a translator of the witnesses' stories in the TRC public hearings, thus bearing witness to the suffering of victims.

As already anticipated, the play includes extracts of verbatim testimonies from the TRC victim hearings, and the question relating to how to do justice to the witnesses' stories on the stage became a central issue. In his "Director's note" to his performance, Kentridge identifies the choice of puppetry as the only "ethical" solution in order to respect those people whose stories the play was using: 
There seemed to be an awkwardness in getting an actor to play the witnesses - the audience being caught halfway between having to believe in the actor for the sake of the story, and also not believe in the actor for the sake of the actual witness who existed out there but was not the actor. Using a puppet made this contradiction palpable. There is no attempt to make the audience think the wooden puppet or its manipulator is the actual witness. The puppet becomes a medium through which the testimony can be heard. (Ubu xi)

Each witness-puppet is flanked by a visible puppeteer and a translator, with the latter standing in a booth and translating the testimony into English. ${ }^{3}$ This triangular formation that controls the puppets (puppeteer/puppet/translator) perfectly captures the complex relationship between testimony, translation and documentation and exposes some weaknesses in the testimonial process adopted by the TRC. It is not a surprise that, commenting on another theatre performance about the TRC, The Story I Am About To Tell, ${ }^{4}$ Kentridge points out that the choice to have real TRC witnesses performing in the play is "only a partial solution [...] Because what the 'real' people give is not the evidence itself, but performance of the evidence. There is a huge gap between the testimony at the Commission and its performance on the stage" (Ubu xiii). On the other hand, the artifice of puppetry signals how the translations are always at a remove from the original testimony, and how the original testimony itself is at a remove from the moment of the original traumatic experience.

Consistent with these observations, Graham defines Ubu as a "theatre of displacement" ("The Truth Commission" 18) because it creates a certain degree of distance between the audience and the witnesses, providing the audience with the opportunity to focus on victims' stories of suffering and to reflect on the difficulty of articulating trauma. Hutchison also asserts that the device of puppetry invites the audience "to engage with particular kinds of abuse without overly individualizing the experiences to emphasize the centrality of institutional violence and culpability in apartheid" (59). By primarily concentrating on the stories of trauma rather than on individuals - the victimpuppets are not in fact identified - Ubu and the Truth Commission successfully alludes to the apartheid state as an institutionalized system of oppression and segregation which affected the whole South African society.

The screen behind the stage represents another distancing device, and reproduces the violence carried out by $\mathrm{Pa}$ Ubu through the projection of images, documentary footage, and cartoon clips. In this regard, Geoffrey Davis pinpoints three main functions of these projections, namely, "to document Pa Ubu's guilt (images of detention, hanging, torture, and parcel bombs), to evoke the fate of his victims (the recurring imagery of death: bones, skulls, skeletons, gravestones) and to suggest his fear of exposure (the watching eye, the camera)" (69). The effect of these projections of violence is heightened by the contrast deriving from Pa Ubu's rehearsed and self-exonerating deposition before the Amnesty Committee. Fearing the Truth Commission's demand for full disclosure, the man has two options, "conceal or reveal" (Ubu 55), and, at first, he

3. In order to replicate the witnesses' possibility to speak in the language of their choice in the TRC public hearings, the statements of these witness-puppets are first given in an indigenous African language - Xhosa - and then translated into English.

4. This is a play made by a support group for survivors who have given evidence before the Truth Commission. It was performed at the Market Theatre in Johannesburg on 10 June 2010. The text has, however, not been published. 
chooses the former by stuffing some documents in Niles, the crocodile. ${ }^{5}$ But after Ma Ubu's attempt to expose his crimes through the media, $\mathrm{Pa}$ Ubu decides to take his shadow's advice and "blame all on politics and beguile the Commission" (57). He indeed betrays his loyal assistant Brutus by filling his belly with some incriminating evidence, thus ensuring that the three-headed dog will be punished for his master's crimes. Brutus will then be condemned to three different sentences corresponding to each head: the head of political affairs is retired on full pay, the head of the military is sentenced to "thirty years in the leadership of the new state army" (63), while the head representing the actual agent of "these ghastly deeds" is condemned to 212 years' imprisonment.

After Brutus has been sentenced, Pa Ubu finally delivers his well-rehearsed speech, and his performance before the Commission is disturbingly convincing. First, he claims not to have known what was really going on and shifts the burden of guilt on to "those above [him]; those below [him]; those beside [him]" (67). Then, he depicts himself as a good soldier who was only serving his country; finally, he concludes his well-constructed plea by expressing his remorse for the people he killed: "Remorse, I can assure you, a lot, a hell of a lot" (69). The play ends with Pa Ubu, pardoned for his crimes, sailing off with Ma Ubu into the setting sun towards "a fresh start [...] A new beginning. / A bright future" (73). This ending unquestionably leaves the audience confused and perplexed about the cost of reconciliation and the implications of the amnesty deal pardon in exchange for a full confession - established by the Commission. The story of $\mathrm{Pa}$ Ubu thus suggests that the TRC is a flawed process, especially in connection with the issue of amnesty, which here is easily achieved through the protagonist's concealment and artifice, and not through repentance and a sincere full confession. Ubu and the Truth Commission exposes how the truth can be manipulated and distorted by the perpetrator, thereby undermining and questioning the TRC's very terms for reconciliation.

Notbing But the Truth is John Kani's debut as a solo playwright, ${ }^{6}$ and, although differing from Ubu and the Truth Commission for its mimetic and naturalistic narrative style, the play likewise functions as a kind of indirect commentary on the TRC and questions the concepts of truth, memory, justice, and reconciliation underpinning the work of the Commission. By enacting the tensions and the conflicts within the microcosm of one family, the play exposes both the complexity of establishing the truth (here, in defining a liberation hero) and the narrowness of the scope of the TRC, which excluded the most ordinary aspects of apartheid trauma. The protagonists are Sipho Makhaya, Assistant Chief Librarian at the Port Elizabeth Public Library, and his daughter Thando, who is a teacher and also works as an interpreter at the Amnesty hearings of the TRC. The play is set in motion by the news of the death of Sipho's brother, Themba, the famous liberation hero who went to London in exile and did not go back home to South Africa, although the political situation had changed. Themba's daughter (and Sipho's niece) Mandisa is expected to arrive and bring back her father's body for burial in his ancestral

5. Aside from victim puppets, there are also perpetrator puppets, namely, Niles the crocodile and Brutus the dog. While Niles plays the role of the advisor, Brutus is Pa Ubu's real henchman and assists his master in his heinous crimes. He is a dog with three heads, representing respectively the foot soldier, the general and the politician.

6. John Kani has been involved in creating plays since he joined The Serpent Players in 1965 and he has collaborated with Athol Fugard, Winston Ntshona and other theatre practitioners such as Nomhle Nkonyeni and Fats Bookholane, who later distinguished themselves on the South African and international stage. 
soil. ${ }^{7}$ Loss and memory thus become central concerns in Nothing But the Truth, and are explored in the intimate domestic space of Sipho's family, rather than being exposed in the public eye of the TRC proceedings. Graham observes that it is no coincidence that Sipho should be a professional librarian, whose task entails engaging with history, "given the play's emphasis on memorializing, encoding and archiving the past" ("I was thousands!" 79).

The play also becomes a means through which the author can comment on and evaluate the amnesty process, given Thando's involvement with the Commission as an interpreter. In act II, scene I, Thando and Mandisa return from a session of the TRC amnesty hearings and begin to discuss the effectiveness and adequacy of the amnesty process in comparison with other ways to serve justice - the Nuremberg-style trial, for instance. On the one hand, Mandisa attacks the choice of a truth commission and shows her indignation at the granting of amnesty to someone who had committed murder but met the requirements requested by the TRC: "That's all there is to it? No more. We can all go home. All is forgiven. Somebody died for God's sake. Someone is guilty" (Nothing 27). On the other hand, Thando offers counterpoints to these outsider's perceptions of the Commission - although her father was from South Africa, Mandisa was born and raised in England. Thando places particular emphasis on her cousin's foreign background, asserting that overseas people tend to oversimplify the situation but cannot completely understand the needs of South Africa:

Typical of someone sitting 6000 miles away. In a comfortable house in London, observing the whole situation with a pair of binoculars. You and your periodic amnesia, choosing to remember and forget as you wish. [...] No, your anger is selective. We, who stayed here. We who witnessed first hand the police brutality. We who every Saturday buried hundreds of our young brothers and sisters shot by the police, dying in detention, dying because of orchestrated black on black violence, accept the TRC process. You have no right to question that. [...] If all those who suffered can forgive, then so can you. If our President can ask us to work for a better life for all of our people, so can you. (29-30)

At this point, Sipho intervenes in the discussion and defends his daughter's perspective by explaining to the skeptical Mandisa that this is "African humanity, Ubuntu, not generosity" (30). But some pages later, Sipho questions the validity of the amnesty process in relation to his son Luvuyo's death, for which he has always blamed his brother Themba and his political ideas of active struggle. Sipho wants a senior investigating officer to be appointed in order to re-open Luvuyo's case and discover the identity of the white policeman who shot his son. Rejecting the amnesty deal of forgiveness in exchange for a full confession, he demands that the culprit be charged "with the murder of Luvuyo Makhaya, the son of Mr Sipho Makhaya" (53) and put in jail. Only after the culprit has realized that he is serving time in prison for killing his son will Sipho accept that he applies for amnesty. The question of forgiveness, however, remains unanswered. Thando, in fact, asks her father whether he will be able to forgive Luvuyo's murderer after the sentence and the application for amnesty, but Sipho does not answer (58) and contrasts the act of forgiveness with justice: 'You don't get it, do you? This whole fucking country doesn't get it. It's not about me. It's not about me being happy or not,

7. Later on, the audience, as well as Sipho, discovers that Themba has been cremated without his original family's permission and Mandisa carries her father's ashes, and not body. The news unsettles Sipho and creates further tension amongst the family. 
forgiving him or not. It's about justice. That's what it's about. So that my soul can rest. So that I can say to myself 'yes, justice has been done"' (54).

To borrow Hutchison's words, this play illustrates how "the macrotruths of the TRC are complicated when placed alongside the 'microtruths' of the everyday lived experiences of individual people" (74). In contrast to his famous brother, the hero of the struggle, Sipho and his stories of suffering represent the most ordinary aspects of apartheid trauma, and, as such, they were neglected by the TRC proceedings. Indeed, the story of Sipho's life has always been characterized by "losses" and "takings" as side effects of the cumbersome presence of his brother Themba. For instance, Sipho had to give up his dream of attending university to support his brother financially and allow him to graduate; he lost his son because his brother had infected him with political activism; finally, his wife abandoned him because of her extramarital affair with Themba. These revelations function at two different levels: first, they undermine Themba's shining image as a liberation hero - "He was involved. He was in the Struggle, but on his terms. He got what he wanted from the Struggle - money, women and fame," (Nothing 48) Sipho thus emphasizes. Secondly, all these examples of ordinary suffering fell out of the TRC's ambit and strict definition of gross human rights violations, suggesting that the measures adopted by the Commission were inadequate to heal and reconcile all the traumatic microtruths of the South African people. This sense of betrayal is intensified by the news that a young man, coming back from exile, has been favored over Sipho for the position of Chief Librarian at the Public Library because of his political activist past, although the old man has been working there for almost thirty-three years. This disappointment conflates with his resentment against his brother Themba and his "Struggle," and results in the following outcry where Sipho claims his right to have been suffering like every black person in the apartheid era:

I was part of the Struggle. I too suffered as a black person. I went to the marches as everyone else. I might not have been detained. I might not have been on Robben Island. I did not leave this country, but I suffered too. The thousands that attended those funerals on Saturdays, that was me. The thousands that were tear gassed, sjamboked by the police, mauled by Alsatian dogs, that was me. When Bishop Tutu led thousands through the streets of white Port Elizabeth, that was me. I WAS THOSE THOUSANDS! I too deserved some recognition, didn't I?

No! No more! It's payback time. The taking stops right here and now. [...] The taking must stop. I want my son back. De Klerk must come back from wherever he is. He has to tell me who killed my son and why. I want to know what this government is going to do about it. (52)

Sipho's speech calls into question one main assumption in the TRC's operations - the notion that revealing and documenting the truth about gross human rights violations committed under apartheid was in itself a sufficient basis to heal and reconcile the whole country. As underscored by Graham, the play does not offer a definitive or immediate solution to this desire for justice, but it implies the need for some sort of restoration and concrete transformations to accompany the compiling work carried out by the TRC. Indeed, Sipho's resolution to create a new African Public Library in New Brighton township - "It will be the first in this country" (59) - might be interpreted as a first concrete attempt to reorganize space in post-apartheid South Africa and provide some sort of restoration to African people ("I was thousands!" 81). 
In his introduction to Nothing But the Truth, Zakes Mda defines the play as a postapartheid work, belonging to a body of similar texts that has been called "Theatre for Reconciliation." Nonetheless, Mda acknowledges that Kani's text denounces the shortcomings of the project of reconciliation adopted by the TRC, showing how art, and theatre in particular, can contribute to the negotiation with conflicting and traumatic memories, and invite the reader/audience to further reflections. This echoes Jane Taylor's words about Ubu and the Truth Commission: "it is my feeling that through the arts some of the difficult and potentially volatile questions, such as why we betray or abuse each other, could be addressed without destabili[zing] the fragile legal and political process of the TRC itself" (Ubu iii). Although adopting different strategies and perspectives, both plays expose some flaws of the Truth Commission, with particular reference to the multi-layered concept of truth and its representation, and, consequently, to the core assumption that the disclosure of truth could heal and automatically guarantee reconciliation within South Africa. On the one hand, Ubu reveals the fragile nature of "forensic truth," which can easily be distorted and manipulated to one's own advantage: Ubu distorts the facts to escape prison, thus nullifying the TRC amnesty deal of pardon in exchange for a truthful confession. Conversely, the choice of puppet-witnesses engages with the issue of "truth" from a more personal perspective: this artifice, in fact, avoids the risk of wrongly appropriating people's personal emotions and stories of trauma, and, at the same time, invites the audience to ponder on the complexity of representing traumatic truths on stage.

On the other hand, Nothing But the Truth also addresses both the issues of the amnesty process and the concept of truth, but from different angles. Here, Kani questions the appropriateness and effectiveness of amnesty from the victim's viewpoint, suggesting that the trial system might serve justice in a fairer way. Moreover, the author condemns the TRC's strict definition of "truth" which could be reported at the public hearings namely, extraordinary bodily violations -, thus preventing the majority of people from narrating their personal "microtruths" of daily ordinary trauma. Both plays thereby show how literature makes it possible to deal with contradictory questions, and to engage critically with the past, and with the way this past has been addressed by the Truth and Reconciliation Commission.

Francesca Mussi University of Sussex

\section{Works Cited}

DAvis, Geoffrey V. "Addressing the Silences of the Past: Truth and Reconciliation in Post-Apartheid Theatre." South African Theatre Journal 13.1 (1999): 59-72.

Graham, Shane. "The Truth Commission and Post-Apartheid Literature in South Africa." Research in African Literatures 34.1 (Spring 2003): 11-30.

—. "I was thousands!': Memory, Identity and Space in John Kani's Nothing But the Truth." Theatre Research International 32.1 (2006): 68-84.

Hutchison, Yvette. South African Performance and Archives of Memory. Manchester; New York: Manchester UP, 2013.

JarRY, Alfred. Ubu Roi. 1896. New York: Dover, 2003.

KanI, John. Notbing But the Truth. Johannesburg: Witwatersrand UP, 2002.

KroG, Antjie. Country of My Skull. 1998. London: Vintage, 1999. 
Engaging with the South African Past: The TRC and How Theatre Performs Back

Kuhlamani Support Group. The Story I Am About to Tell. Performance at the Market Theatre in Johannesburg, 10 June 2010. Unpublished.

MARx, Lesley. "Slouching towards Bethlehem: Ubu and the Truth Commission." African Studies 57.2 (1998): 209-20.

Promotion of National Unity and Reconciliation Act, No. 34 of 1995. 28 June 2015 < http://www.justice.gov. za/ legislation/acts/1995-034.pdf>. Consulted 11 December 2015.

TAYLOR, Jane. Ubu and the Truth Commission. Cape Town: Cape Town UP, 1998.

TRC Final Report. 28 June 2015 <http://www.justice.gov.za/trc/report/index.htm>. Consulted 11 December 2015.

Tutu, Desmond. No Future Without Forgiveness. 1999. London: Rider, 2000. 